\title{
OPINI GURU TENTANG PEMANFAATAN GOOGLE CLASSROOM DI ERA NEW NORMAL PANDEMI COVID-19
}

\author{
Eflina \\ SMAN 1 Bakam \\ eflinasuratno@gmail.com
}

\begin{abstract}
Abstrak
Penelitian ini dilakukan berdasarkan kesulitan guru memilih media pembelajaran yang dianggap efektif di masa pandemi covid-19. Tujuan penelitian ini yaitu memberi gambaran tentang opini guru dalam pemanfaatan google classroom sebagai media pembelajaran di era new normal pandemi covid-19. Guru berperan sangat penting untuk tercapainya pendidikan yang berkualitas dan berkarakter. Metode pembelajaran yang disampaikan sebaiknya disajikan secara menarik dan mudah dipahami oleh siswa. Karenanya pemilihan media pembelajaran yang tepat pada situasi darurat, perlu menjadi bahan pertimbangan para guru selaku pemeran utama dalam dunia pendidikan. Penelitian dilakukan dengan metode survey terhadap 31 orang guru yang mengajar di SMAN 1 Bakam dan SMAN 1 Pemali melalui sebaran angket tertutup dan terbuka dalam bentuk google form. Hasil angket disajikan dalam bentuk tabel dan grafik, serta dianalisis secara deskriptif. Terdapat rata-rata $88,7 \%$ guru memberi respon positif dan menyatakan setuju pada keunggulan fitur-fitur google classroom. Hal ini didukung pula dari hasil angket terbuka yang menyatakan bahwa keunggulan google classroom tersebut, memfasilitasi semua kebutuhan guru, mulai dari mengontrol kehadiran siswa, membuat kelas, menyampaikan materi dan penugasan, melakukan evaluasi dan penilaian, serta memberi umpan balik terhadap pekerjaan siswa. Semua data hasil pekerjaan siswa, tersimpan dan terorganisir dengan baik pada google dan berlangsung lama.
\end{abstract}

Kata Kunci: Opini Guru; Google Classroom; Pandemi Covid-19.

\begin{abstract}
This study based of difficult teacher to choose effective learning medium in era of the Covid19 pandemic. Aims the study to provide an overview of the teacher's opinion about the use of google classroom as a learning medium in the new normal era of the Covid-19 pandemic. Teachers play a very important role in achieving quality and character education. The learning method that is delivered should be presented in an attractive manner and easily understood by students. Therefore, choosing the right learning media in an emergency situation needs to be taken into consideration by teachers as the main players in the world of education. The research was conducted by surveying 31 teachers who taught at SMAN 1 Bakam and SMAN 1 Pemali through closed and open questionnaires in the form of google form. The results of the questionnaire were presented in tables and graphs, and were analyzed descriptively. There was an average of $88.7 \%$ of teachers giving positive responses and agreeing on the advantages of the Google classroom features. This is also supported by the results of an open questionnaire which states that the advantages of the google classroom are facilitating all teacher needs, starting from controlling student attendance, creating classes, delivering materials and
\end{abstract}




\section{Edutainment : Jurnal Ilmu Pendidikan dan Kependidikan}

Volume 8 Nomor 2 Edisi Juni - Desember 2020

assignments, conducting evaluations and assessments, and providing feedback on student work. All data on student work is stored and well organized on Google and lasts a long time.

Keywords: Teachers Opinion; Google Classroom; The Covid-19 Pandemic.

\section{PENDAHULUAN}

Pandemi Corona Virus Desease 2019 atau lebih dikenal dengan pandemi covid19 telah mempengaruhi sebagian besar aspek kehidupan negara secara global, termasuk dunia pendidikan di Indonesia. Semua sekolah baik dari tingkat Pendidikan Usia Dini (PAUD), Pendidikan Dasar, Pendidikan Menengah maupun Pendidikan Tinggi tidak dapat melangsungkan kegiatan pembelajaran di sekolah secara tatap muka, melainkan pembelajaran secara daring. Tentu saja, perubahan pola pembelajaran ini memberi dampak yang luar biasa kepada guru selaku tenaga pendidik, siswa maupun orang tua. Sementara itu, tujuan pendidikan untuk menghasilkan pribadi yang unggul dan berkarakter serta siap di dunia kerja tetaplah menjadi fokus utama pendidikan. Kegiatan tatap muka yang dilaksanakan di sekolah akan membangun interaksi sosial dan psikologis antara guru dan siswa.

Hasil penelitian yang yang ditulis oleh Jamilah \& Mulyadi (2020) terdapat beberapa masalah dalam pembelajaran daring yang dialami oleh mahasiswa, antara lain penguasaan teknologi informasi yang masih kurang, kuota data internet, jaringan internet yang tidak menjangkau, masalah ekonomi yang dialami orang tua.

Bukanlah suatu hal yang mudah bagi guru, siswa dan orang tua untuk melakukan pembelajaran daring, karena pola ini sangat jarang dilakukan di dunia pendidikan kita. Guru ditantang untuk memanfaatkan teknologi secara tepat agar penyampaian tujuan pembelajaran dapat dicapai. Ada banyak aplikasi yang dapat dimanfaatkan melalui android seperti WhatsApp Group (WAG), zoom meeting, webex, microsoft teams, google classroom, dan lain-lain. Masing-masing aplikasi memiliki keunggulan dan kekurangan masingmasing.

Pada awal pandemi dan ditetapkannya Belajar Dari Rumah (BDR) demi keselamatan siswa sebagai generasi bangsa, pengalaman penulis dan sebagian besar rekan guru di sekolah menggunakan WAG sebagai media pembelajaran daring untuk menyampaikan materi, memberi tugas dan pengumpulan tugas siswa. Akibatnya kapasitas memori gawai menjadi cepat penuh. Hal yang sama dialami para siswa. Memang penggunaan WAG lebih mudah dan familiar bagi siswa. Akan tetapi, guru mengalami kesulitan menyeleksi tugas- 


\section{Edutainment : Jurnal Ilmu Pendidikan dan Kependidikan}

Volume 8 Nomor 2 Edisi Juni-Desember 2020

tugas siswa yang dikumpulkan, dan mempunyai banyak grup kelas. Mengingat pembelajaran daring diperkirakan dalam waktu yang cukup lama, maka guru perlu memikirkan media lain yang bisa menampung dan mengorganisir kegiatan pembelajaran secara lengkap dan aman.

Media pembelajaran merupakan komponen pembelajaran yang dipilih sedemikian rupa agar pembelajaran dapat berlangsung secara efektif. Menurut Sukiman (2012) yang dimaksud dengan media pembelajaran adalah segala sesuatu yang dapat digunakan untuk menyalurkan pesan dari pengirim ke penerima, sehingga merangsang pikiran, perasaan, perhatian dan minat serta kemauan peserta didik sedemikian rupa sehingga proses belajar terjadi dalam rangka mencapai tujuan pembelajaran secara efektif.

Selanjutnya, disampaikan pula bahwa terdapat beberapa kegunaan praktis dari penggunaan media pembelajaran, antara lain: 1) memperjelas penyajian pesan dan informasi sehingga dapat memperlancar dan meningkatkan proses dan hasil belajar; 2) meningkatkan dan mengarahkan perhatian anak sehingga dapat menimbulkan motivasi belajar, interaksi yang lebih langsung antara peserta didik dan lingkungannya, kemungkinan peserta didik untuk belajar sendiri sesuai dengan kemampuan dan minatnya; 3) dapat mengatasi keterbatasan indera, ruang, dan waktu.

Google classroom merupakan salah satu media pembelajaran daring yang memiliki kegunaan untuk mengatasi masalah pembelajaran berkaitan dengan keterbatasan indera, ruang dan waktu serta memiliki beberapa kelebihan. Google classroom merupakan layanan web gratis yang dikembangkan oleh google untuk sekolah, yang bertujuan untuk menyederhanakan membuat, mendistribusikan dan menilai tugas tanpa harus bertatap muka. Tujuannya yaitu untuk merampingkan proses berbagi file antara guru dan siswa (Wikipedia, 2020). Sedangkan menurut Ningrum (2020) pembelajaran google classroom adalah pembelajaran online jarak jauh dimana guru dan siswa bisa setiap saat dapat bertatap muka melalui kelas online google classroom dan siswanya nanti dapat belajar, menyimak, membaca, dan mengirim tugas dari jarak jauh.

Adapun kelebihan google classroom menurut Janzem dalam Iftakhar (Durrahman, 2018), yakni mudah digunakan, menghemat waktu, berbasis cloud, fleksibel, dan gratis. Hal ini yang menjadi pertimbangan bahwa google classroom tepat digunakan untuk di sekolah dasar. Hasil penelitian Durrahman (2018) mengatakan bahwa terdapat $59,6 \%$ respon peserta diklat sangat menyenangkan 


\section{Edutainment : Jurnal Ilmu Pendidikan dan Kependidikan}

Volume 8 Nomor 2 Edisi Juni - Desember 2020

menggunakan google classroom dan 56,6\% respon sangat setuju google classroom dapat membantu tugas peserta diklat. Selain itu, penelitian yang dilakukan Sabran \& Sabara (2020) menyatakan bahwa pembelajaran dengan google classroom cukup efektif dalam aspek perencanaan pembelajaran, perancangan dan pembuatan materi, interaksi pembelajaran, dan evaluasi pelaksanaan pembelajaran.

Penelitian Ningrum menyimpulkan bahwa persepsi guru terhadap pelaksanaan pembelajaran google classroom, yakni dapat menyampaikan materi secara rinci dengan poin-poin penting, dapat menyampaikan video secara efektif, membuat evaluasi lebih mudah, namun terkendala pada akses internet dan kurangnya kesiapan siswa dalam mengikuti pembelajaran digital.

Pemanfaatan google classroom sebagai media pembelajaran yang cukup efektif akan dipengaruhi oleh kemampuan guru dalam menguasai pembelajaran berbasis teknologi. Dalam hal memilih media pembelajaran daring yang efektif, berdasarkan pengamatan dan pengalaman penulis, guru masih mengalami kesulitan karena keterbatasan ilmu teknologi yang dipahami para guru, khususnya di SMAN 1 Bakam dan SMAN 1 Pemali. Berdasarkan masalah tersebut, maka salah satu media yang bisa dipilih guru yaitu memanfaatkan aplikasi google classroom dalam melaksanakan pembelajaran secara daring, sebagaimana sebelumnya secara resmi telah digunakan sebagai media pembelajaran di perguruan tinggi selama pandemi covid-19. Akan tetapi tidak semua guru sekolah menengah menerapkan pola pembelajaran daring dengan google classroom. Oleh karena itu, penulis merasa perlu untuk melakukan penelitian yang berkaitan dengan opini guru tentang pemanfaatan google classroom dalam pembelajaran di masa pandemi covid-19, khususnya untuk masa new normal saat ini.

\section{METODE PENELITIAN}

Metode penelitian yang digunakan yaitu metode survei, karena membutuhkan fakta-fakta dan keterangan yang berkaitan dengan permasalahan serta hasilnya dapat digunakan dalam pengambilan keputusan selanjutnya. Hal ini diperkuat oleh Nazir (2009) yang mengatakan bahwa metode survei adalah penyelidikan yang diadakan untuk memperoleh fakta-fakta dari gejalagejala yang ada dan mencari keteranganketerangan secara factual, baik tentang institusi sosial, ekonomi atau politik dari suatu kelompok ataupun suatu daerah. Dalam metode survei juga dikerjakan evaluasi serta perbandingan-perbandingan terhadap hal-hal yang telah dikerjakan orang dalam menangani situasi atau masalah serupa dan hasilnya dapat digunakan dalam pembuatan rencana dan 
Edutainment : Jurnal Ilmu Pendidikan dan Kependidikan

Volume 8 Nomor 2 Edisi Juni-Desember 2020

pengambilan keputusan di masa mendatang.

Sampel diambil dari 31 orang guru dari dua sekolah, yakni SMAN 1 Bakam dan SMAN 1 Pemali. Waktu penelitian ini dilakukan pada bulan Agustus tahun pelajaran 2020/2021. Pengumpulan data dilakukan melalui angket tertutup dan terbuka yang disebarkan melalui google form. Angket tersebut memuat tentang opini guru terhadap pelaksanaan pembelajaran di masa pandemi covid-19 dan pemanfaatan google classroom sebagai alternatif pembelajaran daring. Hasil angket tertutup disajikan dalam bentuk tabel dan grafik. Analisis hasil angket dilakukan secara deskriptif.

\section{HASIL DAN PEMBAHASAN}

Proses Belajar Mengajar di Sekolah di

\section{Masa Pandemi Covid-19}

Angket ini berisikan delapan pertanyaan tertutup yang memuat jawaban Setuju atau Tidak Setuju terhadap pelaksanaan Proses Belajar Mengajar (PBM) di sekolah selama masa pandemi. Adapun hasil yang diperoleh dapat dilihat pada tabel berikut:

Tabel 1. Hasil Angket tentang PBM Selama Masa Pandemi

\begin{tabular}{|c|c|c|c|}
\hline No. & Pernyataan & $\begin{array}{l}\text { Setuju } \\
(\%)\end{array}$ & $\begin{array}{l}\text { Tidak } \\
\text { Setuju } \\
(\%)\end{array}$ \\
\hline 1 & $\begin{array}{l}\text { Pandemi covid- } \\
19 \\
\text { membahayakan }\end{array}$ & 96,8 & 3,2 \\
\hline
\end{tabular}


Edutainment : Jurnal Ilmu Pendidikan dan Kependidikan

Volume 8 Nomor 2 Edisi Juni - Desember 2020

melaksanakan

pembelajaran

berbasis IT

secara

menyeluruh

Sedangkan hasil yang disajikan dalam bentuk grafik dapat dilihat pada gambar berikut:

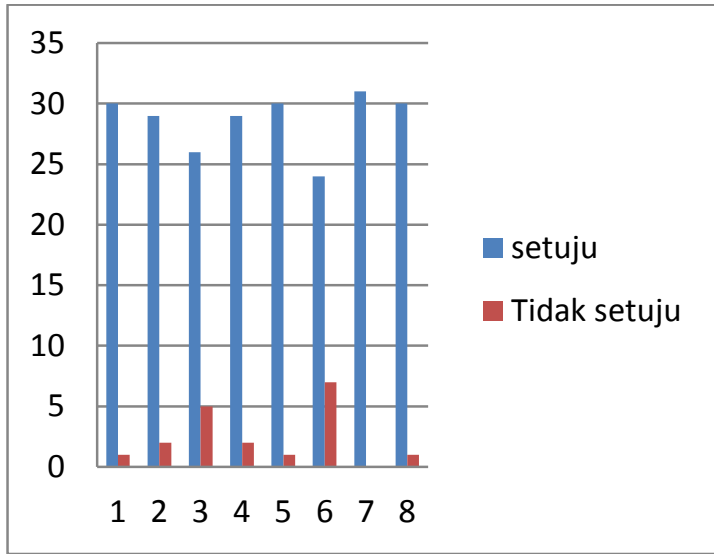

Gambar 1. Grafik Hasil Angket PBM Selama Masa Pandemi

Berdasarkan tabel dan grafik 1, dapat dijelaskan bahwa sebanyak $96,8 \%$ atau 30 orang guru menyatakan setuju bahwa Pandemi Covid-19 membahayakan keselamatan peserta didik dan $93,5 \%$ atau 28 orang setuju menyatakan pembelajaran tatap muka pada sekolah di zona merah tidak dilaksanakan, melainkan dilakukan secara daring saja. Pembelajaran secara tatap muka sebaiknya dilakukan pada sekolah yang berada di zona kuning atau hijau $(83,9 \%)$. Hal ini menunjukkan betapa pentingnya keselamatan peserta didik bagi para guru sehingga kegiatan pembelajaran di sekolah dialihkan menjadi pembelajaran berbasis daring. Akibatnya para guru harus menguasai IT sebagai media pembelajaran daring $(96,8 \%)$. Sedangkan sekolah yang berada di zona kuning dan hijau dapat melaksanakan PBM (83,9\%) dengan mengikuti protokol kesehatan yang telah ditetapkan setelah mendapat izin dari Dinas Pendidikan dan Satuan Tugas wilayah kabupaten dimana sekolah tersebut berada. Proses pembelajaran pun dilakukan dengan model kombinasi daring dan luring, dengan tetap memperhatikan kenyamanan peserta didik dan guru dari aspek jumlah peserta didik, kelengkapan sarana prasarana sekolah, dan pelayanan kesehatan.

Pemanfaatan Google Classroom sebagai Media Pembelajaran Daring

Pada aspek ini, terdapat dua jenis angket yang digunakan, yakni angket tertutup dan angket terbuka. Angket tertutup berisi 12 pertanyaan yang berkaitan dengan pendapat guru tentang google classroom sebagai media pembelajaran daring di era new normal pandemi covid19. Sedangkan angket terbuka merupakan opini responden (guru) sebagai penguatan terhadap angket tertutup yang diberikan penulis. Berikut hasil analisis angket responden yang disajikan dalam bentuk tabel 2. 
Edutainment : Jurnal Ilmu Pendidikan dan Kependidikan

Volume 8 Nomor 2 Edisi Juni-Desember 2020

Tabel 2. Hasil Angket tentang

Pemanfaatan Google Classroom

\begin{tabular}{llll}
\hline \multirow{2}{*}{ No } & Pernyataan & Setuj & Tidak \\
$\cdot$ & $\mathrm{u}$ & Setuju \\
& & $(\%)$ & $(\%)$ \\
\hline
\end{tabular}

\begin{tabular}{|c|c|c|c|}
\hline 1 & $\begin{array}{l}\text { Rencana } \\
\text { Pelaksanaan } \\
\text { Pembelajara } \\
\text { n (RPP) } \\
\text { Daring } \\
\text { disusun } \\
\text { seperti RPP } \\
\text { pembelajara } \\
\text { n tatap muka }\end{array}$ & 54,8 & 45,2 \\
\hline 2 & $\begin{array}{l}\text { Google } \\
\text { classroom } \\
\text { sebagai } \\
\text { media } \\
\text { pembelajara } \\
\text { n moda } \\
\text { daring lebih } \\
\text { efektif } \\
\text { dibandingka } \\
\text { n aplikasi } \\
\text { lainnya }\end{array}$ & 67,7 & 32,3 \\
\hline 3 & $\begin{array}{l}\text { Penyampaia } \\
\mathrm{n} \text { materi } \\
\text { pembelajara } \\
\mathrm{n} \text { hanya } \\
\text { diambil dari } \\
\text { youtube dan } \\
\text { internet } \\
\text { sebagai } \\
\text { sumber } \\
\text { belajar }\end{array}$ & 12,9 & 87,1 \\
\hline 4 & $\begin{array}{l}\text { Membuat } \\
\text { video } \\
\text { pembelajara } \\
\mathrm{n} \\
\text { membutuhka } \\
\mathrm{n} \text { waktu yang } \\
\text { lama }\end{array}$ & 51,6 & 48,4 \\
\hline 5 & $\begin{array}{l}\text { Pembelajara } \\
\text { n di era new } \\
\text { normal } \\
\text { memberi } \\
\text { motivasi } \\
\text { guru dan } \\
\text { peserta didik } \\
\text { untuk }\end{array}$ & 96,8 & 3,2 \\
\hline
\end{tabular}

\begin{tabular}{|c|c|c|c|}
\hline & $\begin{array}{l}\text { mengenal } \\
\text { pembelajara } \\
\mathrm{n} \text { berbasis IT }\end{array}$ & & \\
\hline 6 & $\begin{array}{l}\text { Guru } \\
\text { termotivasi } \\
\text { membuat } \\
\text { powerpoint } \\
\text { sebagai } \\
\text { media } \\
\text { pembelajara } \\
\text { n }\end{array}$ & 86,7 & 13,3 \\
\hline 7 & $\begin{array}{l}\text { Penyampaia } \\
\mathrm{n} \text { materi dan } \\
\text { tugas } \\
\text { melalui } \\
\text { google } \\
\text { classroom } \\
\text { dapat } \\
\text { tersampaika } \\
\mathrm{n} \quad \text { kepada } \\
\text { semua } \\
\text { peserta didik }\end{array}$ & 67,7 & 32,3 \\
\hline 8 & $\begin{array}{l}\text { Membuat } \\
\text { alat evaluasi } \\
\text { lebih mudah } \\
\text { dengan } \\
\text { google } \\
\text { classroom }\end{array}$ & 93,5 & 6,5 \\
\hline 9 & $\begin{array}{l}\text { Penilaian } \\
\text { dapat } \\
\text { dilakukan } \\
\text { langsung } \\
\text { pada google } \\
\text { classroom }\end{array}$ & 96,8 & 3,2 \\
\hline 10 & $\begin{array}{l}\text { Dengan } \\
\text { google } \\
\text { classroom, } \\
\text { pemantauan } \\
\text { kehadiran } \\
\text { dan } \\
\text { keaktifan } \\
\text { peserta didik } \\
\text { lebih mudah } \\
\text { dilakukan }\end{array}$ & 90,3 & 9,7 \\
\hline 11 & $\begin{array}{l}\text { Menu-menu } \\
\text { pada google } \\
\text { classroom } \\
\text { mewakili } \\
\text { kebutuhan }\end{array}$ & 96,8 & 3,2 \\
\hline
\end{tabular}


Edutainment : Jurnal Ilmu Pendidikan dan Kependidikan

Volume 8 Nomor 2 Edisi Juni - Desember 2020

\begin{tabular}{|c|c|c|c|}
\hline & $\begin{array}{l}\text { pembelajara } \\
\mathrm{n}\end{array}$ & & \\
\hline 12 & $\begin{array}{l}\text { Semua kelas } \\
\text { dapat } \\
\text { tergabung } \\
\text { pada google } \\
\text { classroom }\end{array}$ & 87,1 & 12,9 \\
\hline
\end{tabular}

Sedangkan analisis secara grafik disajikan pada gambar 2 berdasarkan jumlah responden:

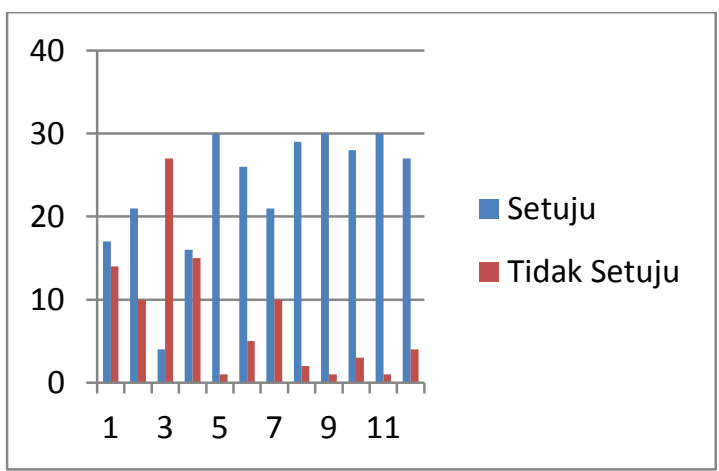

Gambar 2. Grafik Hasil Angket tentang Pemanfaatan Google Classroom

Berdasarkan tabel 2 dan gambar 2, dijelaskan bahwa sebelum melakukan kegiatan pembelajaran daring, guru perlu membuat Rencana Pelaksanaan Pembelajaran (RPP) yang menyesuaikan dengan kondisi pandemi. Hal ini ditunjukkan dengan 54,8\% atau 16 orang guru yang menyatakan Tidak Setuju apabila Rencana Pelaksanaan Pembelajaran (RPP) Daring disusun seperti RPP pembelajaran tatap muka. Guru dapat mengambil sumber belajar yang berasal dari youtube, internet atau membuat video pembelajaran sendiri dan materi slide sebagai media pembelajaran. Semua kegiatan pembelajaran secara daring dituangkan dalam RPP kemudian disampaikan kepada peserta didik melalui aplikasi google classroom.

Analisis hasil angket tentang kelebihan google classroom yang dimanfaatkan oleh guru, dapat dilihat pada butir 7, 8, 9, 10, 11 dan 12, antara lain: Penyampaian materi dan tugas melalui google classroom dapat tersampaikan kepada semua peserta didik, membuat alat evaluasi lebih mudah dengan google classroom, Penilaian dapat dilakukan langsung pada google classroom, dengan google classroom pemantauan kehadiran dan keaktifan peserta didik lebih mudah dilakukan, menu-menu pada google classroom mewakili kebutuhan pembelajaran, dan semua kelas dapat tergabung pada google classroom. Untuk keenam butir pernyataan ini, rata-rata $88,7 \%$ responden memberi respon positif dan menyatakan setuju pada keunggulan fitur-fitur google classroom.

Selain itu, pada angket terbuka menurut responden, tugas-tugas siswa dapat didokumentasikan dengan baik tanpa perlu takut memori android atau laptop menjadi penuh, karena tugas-tugas tersebut tersimpan pada google. Pada saat evaluasi atau pengumpulan tugas, siswa juga tidak dapat melihat hasil evaluasi atau tugas teman yang lain. Melalui google classroom guru juga dapat meng-upload video pembelajaran yang dibuat oleh guru. 
Edutainment : Jurnal Ilmu Pendidikan dan Kependidikan

Volume 8 Nomor 2 Edisi Juni - Desember 2020

Berdasarkan keunggulan tersebut, dari angket terbuka diperoleh 93,5\% responden memanfaatkan google classroom sebagai media pembelajaran daring. Pada awal pembelajaran daring dilaksanakan (bulan Maret sampai Juni 2020), semua responden menggunakan Whats App Grup (WAG) sebagai sarana dan media pembelajaran seperti menyampaikan materi, tugas dan pengumpulan tugas. Selain itu ada juga yang menggunakan google form untuk penilaian, zoom meeting, dan webex. Google classroom baru dimanfaatkan oleh semua guru (SMAN 1 Bakam) pada semester 1 tahun pelajaran 2020/2021.

Selain itu, analisis angket terbuka menggambarkan beberapa kendala dari pemanfaatan google classroom oleh guru. Pada awalnya, hanya 20\% guru yang sudah mengenal dan memahami penggunaan aplikasi google classroom sebelum pandemi, sedangkan $80 \%$ belum mengetahui dan memahami cara-cara menggunakan google classroom. Tetapi seiring waktu, guru dituntut harus belajar dan memahami aplikasi google classroom sebagai media pembelajaran daring. Guru kemudian melaksanakan diskusi kelompok dengan teman sejawat dan belajar otodidak melalui youtube. Dukungan dari pihak sekolah menjadi motivasi terbesar bagi para guru, sehingga pemanfaatan aplikasi google classroom dapat dilakukan dengan efektif.
Kendala yang sama juga dialami oleh siswa. Kurangnya pengetahuan siswa tentang google classroom, membuat siswa kurang termotivasi untuk mengunduh aplikasi google classroom. Selain itu, keterbatasan memori android, ketersediaan paket data dan jaringan, bahkan ada siswa yang tidak memiliki android. Hanya sekitar $75 \%$ siswa yang aktif bergabung pada google classroom yang dibuat guru. Hal ini diperkuat pula dari hasil angket tertutup yaitu butir pernyataan ke-7, yakni Tidak semua peserta didik dapat mengikuti pembelajaran secara daring karena terkendala Android, sinyal dan biaya paket data. Semua responden (100\%) menyatakan setuju terhadap peryataan tersebut.

Untuk mengatasi hal tersebut, tentu saja guru perlu melakukan pendampingan dan pemantauan secara intens, sehingga semua siswa dapat tergabung dalam google classroom yang dibuat guru.

\section{SIMPULAN DAN SARAN}

Berdasarkan pembahasan yang telah diuraikan di atas, dapat disimpulkan bahwa aplikasi google classroom merupakan salah satu aplikasi yang dapat digunakan secara baik bagi para guru dalam melaksanakan pembelajaran daring maupun tatap muka di masa pandemi covid-19 maupun era new normal, karena memiliki keunggulankeunggulan yang memfasilitasi semua kebutuhan guru, mulai dari mengontrol kehadiran siswa, membuat kelas, 
Edutainment : Jurnal Ilmu Pendidikan dan Kependidikan

Volume 8 Nomor 2 Edisi Juni - Desember 2020

menyampaikan materi dan penugasan, melakukan evaluasi dan penilaian, serta memberi umpan balik terhadap pekerjaan siswa. Semua data tersimpan dan terorganisir dengan baik pada google dan berlangsung lama.

Dengan demikian dapat disarankan agar sekolah perlu menyamakan persepsi guru dan fokus memilih media pembelajaran daring seperti google classroom sehingga tujuan pembelajaran dapat tercapai. Sekolah perlu menyediakan sarana informasi berupa forum diskusi berkaitan dengan pelaksanaan pembelajaran dengan google classroom

\section{DAFTAR PUSTAKA}

Durrahman. (2018). Pemanfaatan Google Classroom sebagai Multimedia Pembelajaran bagi Guru Madrasah pada Diklat di Wilayah Kerja Kemenag Kabupaten Cianjur. Jurnal Diklat Keagamaan : Tatar Pasundan, 7(34), 215-221.
Jamilah \& Mulyadi (2020). Dampak Pembelajaran Daring di Tengah Pandemi Covid 19 pada Siswa Sekolah Dasar. Prosiding Diskusi Daring Tematik Nasional 2020, 13-18. Malang: Universitas Muhammadiyah Malang.

Nazir, M. (2009). Metode Penelitian. Bandung: Ghalia Indonesia.

Ningrum, A. (2020). Analisis Pelaksanaan Pembelajaran Google Classroom Era Pandemi Covid-19 Materi Tata Surya pada siswa kelas VII MTs Negeri Salatiga Tahun Pelajaran 2019/2020. Skripsi: IAIN Salatiga.

Sabran \& Sabara, E. (2020). Keefektifan Google Classroom sebagai media pembelajaran. Prosiding Seminar Nasional Lembaga Penelitian Universitas Negeri Makassar, 122-125. Makasar: Universitas Negeri Makasar.

Sukiman. (2012). Pengembangan Media Pembelajaran. Yogyakarta: Pedagogia.

Wikipedia. (2020). Google Clasroom. Diakses pada tanggal 20 Mei 2020. 